\title{
医学と医療の最前線
}

\section{腎臓と加歯現象：腎臓に発現する分子を中心 として}

\section{久米 真司 ${ }^{1)}$ 古家 大祐 ${ }^{2}$ 前川 聡 ${ }^{11}$}

要旨

加齢と共に多くの臓器で機能障害が出現する，腎臓も例外ではなく，多くの人で加齢と共に腎機能低下 が生じる．加齢の要素単独で末期腎不全へ進行することは稀であるが, 加齢に伴う腎機能障害は, 生活の 質の低下や医療介入の制約を生み出す．現在わが国では，栄養状態の改善ならびに医療技術の発展により 寿命が大幅に延長しているが，一方で，このような健康寿命を如何に保証するかという新たな課題に直面 している.この課題に対する数多くの研究成果として，加歯に伴う腎機能障害に関わる分子機構が徐々に 明らかにされつつある. 高血圧や糖尿病などの臨床的要素に加え, 近年, angiotensin IIや酸化ストレス, Klotho, Sirt1，オートファジーといった腎局所の分子機構が腎老化と関連するという興味深い知見が得ら れている. 本稿では, これら老化関連分子と腎老化との関わり，その治療標的としての可能性や問題点を 概説させていただく.

〔日内会誌 $102 ： 2074 \sim 2081 ， 2013 〕$

Key words angiotensin II, Klotho蛋白, Sirt1，オートファジー

\section{はじめに}

進化の過程で獲得した数々の生命維持機構の 破綻を疾患と捉えるのであれば，老化も一つの 疾患ということになろう。しかし，老化が他の 疾患と大きく異なる点は, 全ての生物において 不可避な生命現象であることにある。ヒトでも 加歯令と共に臟器障害が生じる。腎臓も例外では なく, 人種, 性別, そして併存疾患によってそ の速度は異なるものの, ほぼ全てのヒトにおい て加齢と共に腎機能の低下が生じる1)(図 1). 臨
床の現場において，加齢のみが原因で末期腎不 全へ至ることは稀であることから，加齢に伴う 腎機能低下を「疾患」という概念で捉えるべき か否かは議論の余地がある。しかし, 加齢に伴 う腎予備能の低下は，腎疾患の併発時，あるい は, 抗がん薬や造影剤などの腎毒性を有する薬 剂使用時の大きな腎不全発症進展リスクとなる. その点からは,やはり加齢に伴う腎機能低下は, 高齢者における医療上の大きな問題であり，そ の病態解明や進行予防法の開発は必要不可欠な 研究課題である.

健常腎ドナーの腎組織から明らかとされたこ

1) 滋賀医科大学内科学講座糖尿病腎臟神経内科, 2) 金沢医科大学糖尿病-内分泌内科学

The Cutting-edge of Medicine; New therapeutic targets for renal senescence.

Shinji Kume ${ }^{1}$, Daisuke Koya2) and Hiroshi Maegawa ${ }^{1)}:{ }^{1)}$ Department of Medicine, Shiga University of Medical Science, Japan and ${ }^{2}$ Division of Diabetology and Endocrinology, Kanazawa Medical University, Japan. 

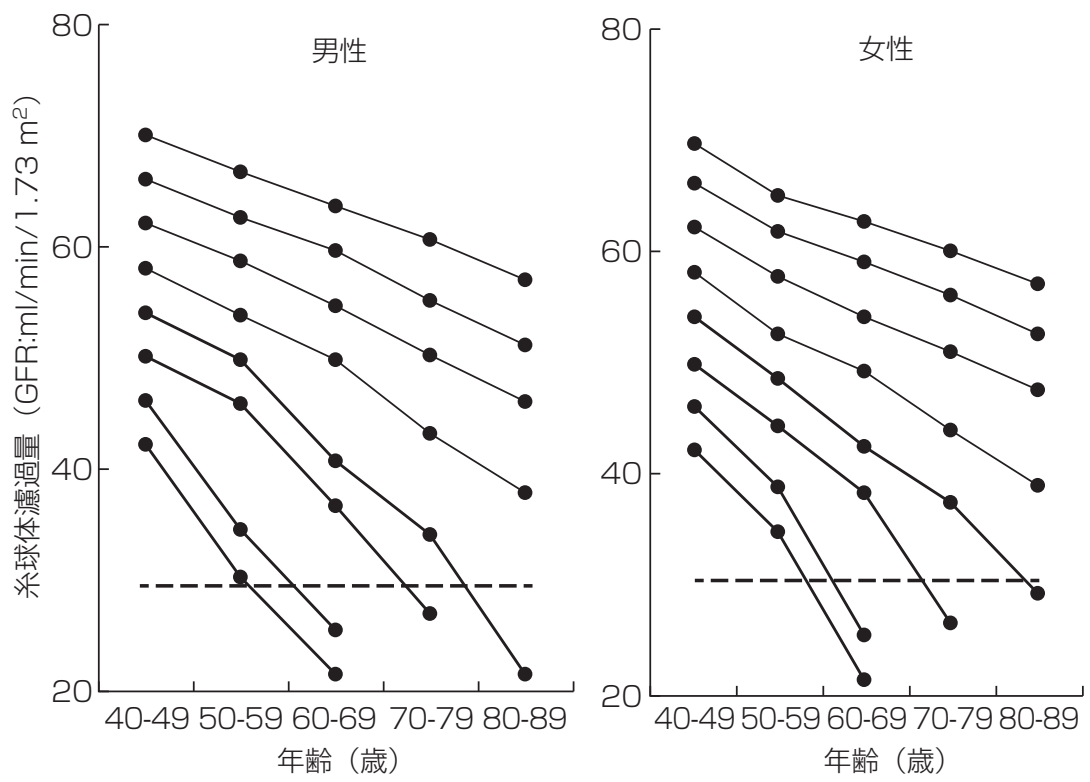

図 1. 日本人における年齢と腎機能低下速度の関係. 性別を問わず, 加齢と共に 糸球体濾過量は低下する.（文献 1 より引用）

とは, 年齢と共に糸球体や間質の線維化が進行 するという事実である。また基礎研究から得ら れた重要な知見は, 線維化速度や腎機能低下速 度を変化させうる制御可能な因子が存在すると いうことである。これら因子を人為的に制御す ることが可能となれば，腎臓のみならず多くの 臓器における老化が抑制され，高齢者における 健康寿命延長の可能性が期待される。これまで の老化研究は, angiotensin II(AII), transforming growth factor $\beta$ (TGF- $\beta$ ), advanced glycation end products (AGEs), 酸化ストレスの異常 充進が腎老化の病態形成に寄与しうることを示 してきた。 また一方で, 動物モデルでの腎老化 防止を目指した研究からは, Klotho遺伝子や, カ ロリー制限に関連した抗老化分子mammalian homolog silent information regulator 2 (Sirt1) あ るいは細胞内浄化機構であるオートファジーに よる腎保護作用が明らかにされつつある。本稿 では,これら腎老化に関わる腎局所の分子機構 に焦点を絞り, 腎老化の病態や新たな腎老化予
防法の可能性について概説させていただく.

\section{1. 腎老化促進因子}

これまでの動物モデルによる腎老化研究の結 果は, 加齢に伴う腎線維化を抑制するための新 規介入方法の可能性を提示している.ここ 10 年の知見からは, 種々のホルモンや代謝産物が 協調して加齢による腎線維化を促進させること が明らかとされている（図 2).

1) angiotensin II (A II)

レニンーアンギオテンシンーアルドステロン (RAA) 系は, 生物が陸上での生命維持を可能に する為に獲得したナトリウムならびに体液の恒 常性維持機構であるが, 現在, RAA系の過剩な 作用が循環器疾患や腎疾患の主病因になってい るという考えに異論はないであろう.その結果, AIIシグナルを如何に抑制するかに研究の中心が 置かれ, 数多くのRAA系阻害薬の開発がすすめ られた. 興味深いことに, AIIシグナルは哺乳類 


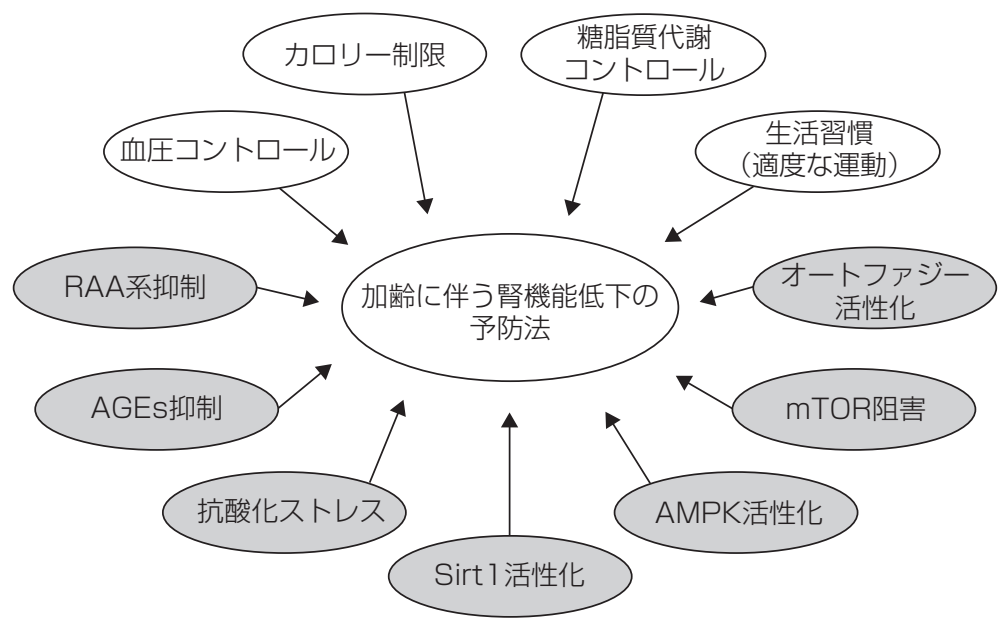

図 2. 加齢に伴う腎機能低下を抑制しうる新規治療法の可能性. 食事療法 や運動による生活習慣の是正に加え, 各種栄養シグナルの是正や抗酸化薬, AGEs阻害薬, RAA系阻害薬が新たな抗腎老化の標的となる可能性がある.

の老化に深く関与している. アンギオテンシン II受容体欠損マウスは野生型に比し長生きする ${ }^{21}$. また高齢ラットにおいて, アンギオテンシン変 換酵素（ACE）阻害薬は，加齢と共に増加する 糸球体内圧の上昇を抑制する結果, 尿蛋白排泄 の増加を抑制する。.さらに，恒常的なACE活性 の阻害やアンギオテンシンII受容体拮抗薬 (ARB) は，系球体ならびに尿細管間質における線維化 抑制効果を有しており，加齢に伴う腎線維化の 抑制効果も期待されている3).では, RAA系阻害 薬は人の健康寿命を延ばすことができるのか? という点に大きな期待が生まれるわけであるが, ヒトを対象とした臨床研究によって加齢に伴う 腎機能の低下を含む臟器の加齢現象を抑制した という知見はこれまでに見られない。また，い ずれの動物実験も加歯の病態が形成される以前 からの薬剤投与や遺伝子改変がなされたもので あり，予防効果が示されたに過ぎない。既に臓 器障害が形成されているような高齢者の臓器保 護に有効であるのか否かは, 安全性も含め更に 検討を深める必要がある。
2) transforming growth factor $\beta$ (TGF- $\beta$ )

線維化は組織の修復過程に不可欠な生理反応 であり, TGF- $\beta$ この過程に不可欠なサイトカイ ンの一つである。しかしAIIと同様に, TGF- $\beta$ 作用の過剩は，腎老化を含む多くの腎疾患にお ける腎線維化を促進させることから，その作用 抑制は腎疾患の治療標的と考えられてきた。血 液や組織の間質に存在するTGF- $\beta$ は, 細胞膜上の 受容体に結合したのち, Smadと呼ばれる細胞内 シグナルの活性化を介して細胞外基質蛋白の転 写を活性化させる結果, 線維化を促進する ${ }^{3)}$. TGF$\beta$ 産生を刺激する因子も多く同定されており, 前 述したAIIをはじめとして, 血小板由来増殖因子, 低酸素, 酸化ストレスやAGEsなど, いずれも加 齢に伴い腎局所に生じうる種々の刺激がTGF- $\beta$ 産生を刺激する. 加歯に伴う TGF- $\beta$ 作用の充進が, 腎線維化を促進していることに疑いの余地はな い. しかし，この作用が加齢に伴う腎組織修復 過程における正常な反応であるのか，それとも 病態としての異常㐫進であるのかは未だ解決さ れていない.TGF- $\beta$ 作用の減弱による腎線維化の 抑制が腎機能の保持に繋がるか否かは今後の検 
討課題である.

3) advanced glycation end products (AGEs : 終末糖化産物)

糖は生体の生命維持に不可欠なエネルギー源 の一つである. 生体内の糖は種々の物質に糖化 修飾をもたらすが, 特に蛋白質のアミノ基に対 する糖化修飾（メイラード反応）の結果生じる 終末糖化産物 (AGEs) は老化と梁く関与してい る. 糖の種類の違いにより NE-(carboxymethyl) lysine (CML), ピラリン, イミダゾロン, ペン トシジン, クロスリン, ピロピリジンなどがあ $ろ^{4)}$. 糖化反応は糖尿病合併症の発症進展に特に 関与するが, 老化によっても生じる. AGEsは組 織に直接沈着すること, あるいはAGE受容体に 結合し, 細胞内シグナルを介した線維化や炎症 などを惹起させることで蔵器障害を引き起こす. AGEsの前駆物質 (メチルグリオキサール)の代 謝によりAGEsによる細胞毒性を軽減しうる glyoxalase I酵素を過剩発現するラットは, 加齢 に伴い生じる腎線維化や腎機能の低下を有意に 抑制することから, 腎老化にAGEsが関与しうる ことは明らかである ${ }^{5)}$. AGEsによる老化促進に 対する予防法としては, 食事由来のAGEsの過剩 摂取を控えること，糖化を抑制するような食事 療法（カロリー制限）を行うことが重要である が, 近年の糖尿病合併症研究領域では, AGEs の産生阻害薬や分解促進薬, AGE受容体拮抗薬, 血中AGEと結合しその作用を減弱するような核 酸 (aptamar) の開発などが進められている ${ }^{6)}$. これらが同様にanti-agingに応用できるか否か, 大変興味深いところである。

\section{4）酸化ストレス}

生体は糖と脂肪酸を材料として細胞内でATP (adenosine triphosphate) 産生を行い, 細胞生命 活動を維持している。このATP産生は主にミト コンドリアで行われており, 大量の酸素を使用 することから，この過程で大量の酸化ストレス を生み出すこととなる，この酸化ストレスは細
胞に強い毒性を示す為, 細胞内には酸化ストレ スを除去する為の高度な抗酸化システムが備え られている. しかし, 加齢に伴う酸化ストレス 除去能力の低下は, 細胞内の酸化ストレスの増 大を生み出し, 更にミトコンドリア機能異常を 引き起こすことで, 酸化ストレスーミトコンドリ ア異常のvicious circleを形成する ${ }^{7)}$. ビタミン製 剂をはじめ, 抗酸化ストレス薬による抗老化の 可能性が期待されてはいるが, 実際の有効性は 未だ不明である. 既に酸化ストレスのvicious circleが出来上がった状況に, 抗酸化ストレス薬と いう対処療法では老化に太刀打ちすることは困 難なのかもしれない.

\section{2. 腎老化抑制因子}

腎老化促進に関わる因子の同定のみならず, 腎老化抑制に関わる因子の同定も同時に進めら れてきた。近年新たに明らかとされた抗腎老化 作用をもつ分子機構について概説させていただ $<$ (図 2).

\section{1) Klotho}

1997 年にKlotho遺伝子を欠損したマウスが早老 の表現系を示すことが明らかとされ8), その後, Klotho蛋白を過剩発現するマウスが長寿となるこ とが報告された9).このように, Klotho蛋白を過 剩に発現させることで，健康に悪影響を与える ことなく長寿をもたらすという事実は, 健康寿 命の延長を目指す我々にとって特筆すべき知見 である.このように, Klotho遺伝子が最も臨床応 用可能な抗老化分子の一つとして着目されるよ うになり,多くのKlotho研究が進められた結果, 腎臓(特に遠位尿細管細胞), 副甲状腺, 脳脈絡

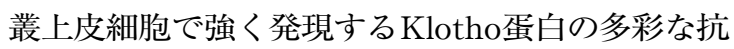
老化メカニズムが明らかとされた。興味深いこ とに, 腎疾患とKlotho発現には密接な関連が存在 している. 前述のKlotho欠損マウスは, 早老の表 現系と共に末期腎不全を呈する。一方で, 腎疾 


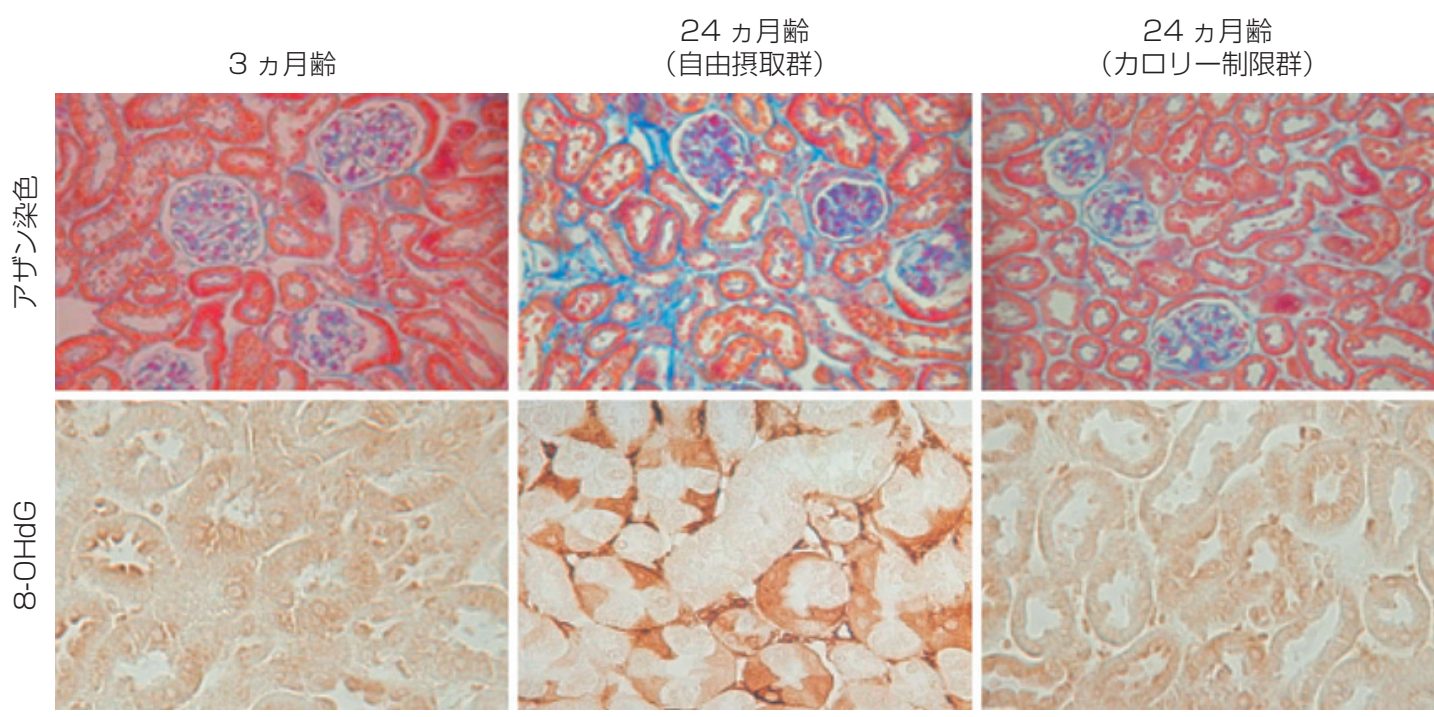

図 3. 自由捸取に比し 40\%のカロリー制限は，マウスにおける加齢に伴う腎糸球体ならびに間質の線維化を 有意に改善し, 細胞内の酸化ストレス (8-OHdG) の蓄積を減少させる. 3 カ月齢の若年マウスの腎臓では 線維化, 酸化ストレスを認めないが, 24 カ月齢の高齢マウスでは線維化 (上段: 青色), 酸化ストレス (下段 : 茶色）が増加する. 一方, この病変は 1 年間のカロリー制限により改善される. (文献 11 より引用)

患における腎内のKlotho発現は有意に低下する. これらの事実は, Klotho発現と腎蔵病の発症進展 の間にはvicious circleが存在すること,更には腎 老化が全身の老化制御に関わるという可能性を も示唆している.分子基盤は明快でないが, Klotho 発現の低下は腎線維化を促進し, Klotho発現の回 復は各種腎疾患モデルの腎病変を改善し得る.

Klotho蛋白の補充投与が可能となれば, 腎老化の 予防ひいては健康寿命の延長が期待できるかも しれない.

2) mammalian homolog silent information regulator 2 (Sirt1)

カロリー制限は下等生物を含む種々の生物に おいて寿命延長をもたらし，哺乳類においては 老化関連疾患の発症を予防しうる可能性が示さ れてきた.この 20 年間, カロリー制限を模倣し, 抗老化をもたらしうる分子機構の解明を目指し た挑戦が世界中で続けられてきた結果, $\mathrm{NAD}^{+}$依 存性ヒストン脱アセチル化酵素（Sirt1）や細胞 内浄化機構の一つであるオートファジーが, そ
の候補として脚光を浴びている.

細胞は細胞内外のエネルギー状態の変化を瞬 時に把握し, 生命活動の変化に直結させる必要 があり，細胞内には細胞内のエネルギー状態を 把握するセンサーが備えられている。 その一つ がSirt1 である.Sirt1 は細胞内のエネルギー欠乏 状態で活性化される脱アセチル化酵素であり, 細胞内NAD (nicotinamide adenine dinucleotide) 濃度の変化を感知するエネルギーセンサーであ $3^{10)}$. 線虫や酵母などの高等生物からマウスなど の哺乳類まで, Sirt1 発現を欠損させると, カロ リー制限による寿命延長, 抗老化効果が減弱消 失する. 哺乳類におけるSirt1 には種々の機能が 備わっており，抗酸化ストレス，ミトコンドリ ア機能の是正, ミトコンドリアの増生, オート ファジーによる異常ミトコンドリアの排除, 糖 新生など生体のカロリー制限時に見られる現象 の多くを調節している. 腎老化とSirt1 との関わ りも明らかとされている.カロリー制限により, マウスの加齢に伴う腎線維化や酸化ストレスの 


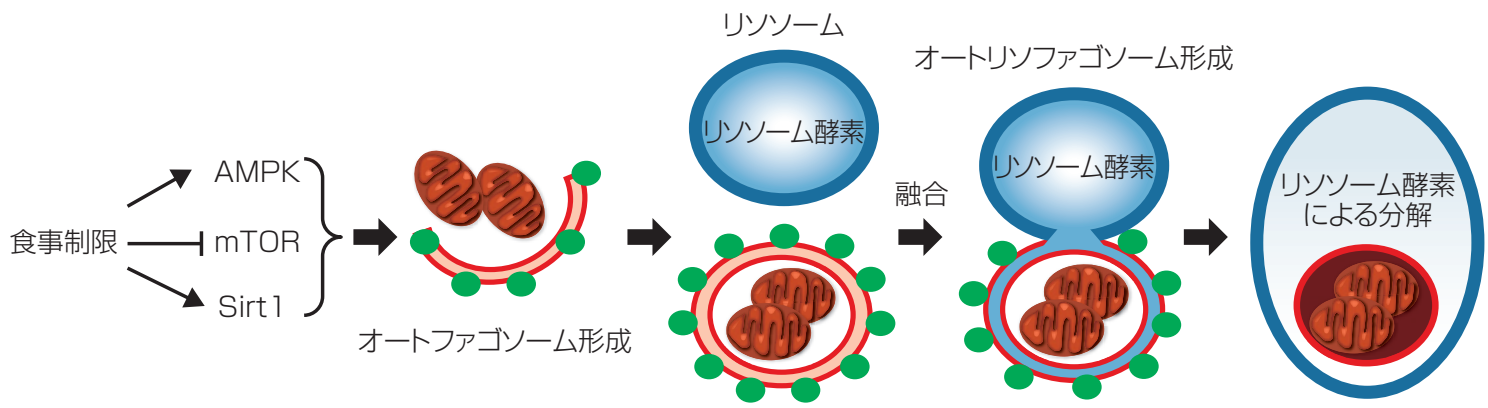

図 4. オートファジー活性化制御機構 : 飢餓状態，異常オルガネラの蓄積が生じると，細胞質内オートファジー 関連蛋白のカスケード経路の活性化が生じ, オートファゴソームが形成される. 分解物質, オルガネラを含むオー トファゴソームはリソソームと融合し (オートリソファゴソーム), リソソーム酵素で分解される. オートファジーの 活性は細胞内エネルギ一感知シグナル（AMPK/mTOR/Sirt1）により制御されており, 食事制限（カロリ一制限・ 飢餓・アミノ酸制限）により活性化される.

増大が抑制されること（図 3)，そして，その改 善にはSirt1 の活性化が必要であることが報告さ れている11).また，Sirt1へテロ欠損マウスでは 腎老化が早期に進行するだけでなく，カロリー 制限による抗腎老化作用が消失してしまうこと も明らかとなっている ${ }^{11}$. その分子機構の検討か らは, Sirt1 活性の低下は細胞内の浄化機構の一 つであるオートファジー活性の低下を介して腎 内の異常ミトコンドリアや酸化ストレスといっ た老廃物の蓄積増加をもたらし，腎老化を促進 させていることが示されている ${ }^{11}$. 加齢とともに 低下するSirt1 活性を維持することが可能となれ ば，腎老化の新たな抑制手段となるかもしれな い. 今後, Sirt1 活性化薬の臨床応用が期待され る.

Sirt1 に加え, 腎臟にはmammalian target of rapamycin (mTOR) ならびにAMP (adenosine monophosphate)-activated protein kinase (AMPK) と呼ばれる細胞内栄養感知シグナルが 存在する ${ }^{12}$. 何れもリン酸化酵素 (キナーゼ) と して働き, 種々の蛋白のリン酸化を介して細胞 の生命活動の制御に寄与している. 前者は過栄 養(インスリンなどの成長因子や糖, アミノ酸) によって活性化され，後者は細胞内飢餓による 細胞内 $A M P$ 濃度の上昇により活性化される. 腎
老化における両シグナルの役割はいまだ明らか とはなっていないが, 前者の活性化は糖尿病性 腎症などの腎病変形成に関わること,またmTOR の選択的阻害薬はマウスの寿命延長をもたらす ことから, mTORの過剩立進が腎老化に関わる 可能性も十分に考えられる. 一方, Sirt1 同様に 飢餓時に活性化されるAMPKの活性化は各種腎 障害モデルの改善をもたらしうることが報告さ れており，カロリー制限による腎保護の一端を 担っている可能性があり, その活性化薬は一つ の抗老化薬として期待される.

3）オートファジー

前述したオートファジーは, 近年種々の老化 関連疾患の発症に関連する分子機構として着目 されている.オートファジーとは日本語にする と「自食作用」と訳される。このオートファジー は飢餓時や異常たんぱく質, 異常オルガネラの 蓄積時に最も強く活性化される.オートファジー の活性化時には, 細胞質内にオートファゴソー ムという新たな隔離膜が形成され，細胞質ごと 標的分子やオルガネラが隔離され, リソソーム へと運搬されたのち，リソソーム酵素により分 解される ${ }^{13)}$ (図 4).このようにオートファジーは 大規模な細胞内分解系であり, 細胞の恒常性維 持に不可欠な役割を果たしている. 近年，この 
オートファジー機能の破綻と種々の疾患とのか かわりが報告されている。腎臓でも, 糸球体上 皮細胞ならびに近位尿細管細胞でオートファジー 活性を消失するマウスを作製すると，それぞれ 加齢に伴う糸球体障害, 尿細管細胞障害の増悪 をもたらす ${ }^{14,15)}$.この結果は, 腎老化においても オートファジーが腎保護的に働いていたことを 示している. 興味深いことに，オートファジー の活性は，前述した 3 つの栄養感知シグナルに より調節されている。栄養感知シグナルの老化 への関わりはオートファジー活性によって説明 できるのかもしれない. 全ての人にオートファ ジーを活性化することが有益なのか否かなど, 未だ多くの議論すべき点は残されているが,オー トファジー活性が低下している状態での再活性 化が治療標的の一つとなり得る事を期待したい.

このように, 栄養と健康寿命は切っても切れ ない関係にあるようである。もちろん, 飢餓や 低栄養の時代に戻ることが良いわけではない. 「過ぎたるは猶及ばざるが如し」とあるように， 過剩な栄養摂取が問題なわけである。生体は長 らく飢餓に晒され，飢餓を克服する為の機能を 進化させてきたが, 栄養状態の改善が寿命延長 をもたらした半面, 過剩な栄養摂取は飢餓時に 発揮しうる細胞内のストレス応答機能を抑制す る結果となり, 生活習慣病や老化の促進に寄与 するという皮肉な結果を生み出している. どれ くらいのカロリーが適切なのか? 残念ながら, ヒトの寿命や健康寿命を標的とした，何十年も の臨床研究を行うことは困難であり, 人の健康 寿命の延長をもたらすための適切な食事介入方 法を規定するのは現時点では難しい. カロリー 制限が有する健康に有用な機能を特異的に引き 出す「カロリー制限模倣薬」が健康寿命の延長 をもたらす一つの特効薬として登場することを 期待したい。 カロリー制限や飢餓時に発揮され る生体の適応反応には, 我々の知らない未知の 能力が隠されている気がしてならない.

\section{3. 結 論}

老化現象は単一の原因で生じるものではなく, 老化を抑制するには個々の臨床的背景に応じた 対応が必要である. 本稿では, 加齢に関わる代 表的な分子，特に近年明らかとされた分子に焦 点を絞り概説させていただいた。勿論, これら の因子以外に多くの分子が複雑に絡み合い老化 は進行する。生物が進化と共に発達させてきた 生命維持機構を正確に把握し, その機構の破綻 と老化との関係を一つ一つ紐解いていくことが 健康寿命の延長を目指した研究には必要と思わ れる。ここで紹介した知見を背景に，新たに多 くの研究者が老化研究に携わって頂き，老化に 関わる新しい発見が生まれる事を祈念している. 本稿が今後の抗老化研究の発展, successful aging達成の一助となれば幸いである.

著者のCOI (conflicts of interest) 開示：本論文発表内容に 関連して特に申告なし

\section{文献}

1) Imai $\mathrm{E}$, et al : Slower decline of glomerular filtration rate in the Japanese general population:a longitudinal 10-year follow-up study. Hypertens Res 31 : 433-441, 2008.

2) Benigni A, et al:Disruption of the Ang II type 1 receptor promotes longevity in mice. J Clin Invest $119: 524-530$, 2009.

3) Heldin $\mathrm{CH}$, et al : TGF-beta signalling from cell membrane to nucleus through SMAD proteins. Nature 390 : 465-471, 1997.

4) Goldin A, et al: Advanced glycation end products:sparking the development of diabetic vascular injury. Circulation $114: 597-605,2006$.

5) Ikeda $Y$, et al : Glyoxalase I retards renal senescence. Am J Pathol 179 : 2810-2821, 2011.

6) Kaida Y, et al:DNA aptamer raised against AGEs blocks the progression of experimental diabetic nephropathy. Diabetes 2013, in press.

7) Finkel T, Holbrook NJ : Oxidants, oxidative stress and the biology of ageing. Nature 408:239-247, 2000.

8) Kuro-o M, et al : Mutation of the mouse klotho gene leads to a syndrome resembling ageing. Nature $390: 45-51$, 
1997.

9) Kurosu H, et al : Suppression of aging in mice by the hormone Klotho. Science 309 : 1829-1833, 2005.

10) Liang F, et al: SIRT1 and insulin resistance. Nat Rev Endocrinol 5 : 367-373, 2009.

11) Kume $\mathrm{S}$, et al : Calorie restriction enhances cell adaptation to hypoxia through Sirt1-dependent mitochondrial autophagy in mouse aged kidney. J Clin Invest 120: 1043$1055,2010$.

12) Inoki $\mathrm{K}$, et al : AMPK and mTOR in cellular energy ho- meostasis and drug targets. Annu Rev Pharmacol Toxicol 52 : 381-400, 2012.

13) Mizushima N, Komatsu M : Autophagy : renovation of cells and tissues. Cell 147 : 728-741, 2011.

14) Hartleben B, et al : Autophagy influences glomerular disease susceptibility and maintains podocyte homeostasis in aging mice. J Clin Invest 120 : 1084-1096, 2010.

15) Kimura $\mathrm{T}$, et al : Autophagy protects the proximal tubule from degeneration and acute ischemic injury. J Am Soc Nephrol 22 : 902-913, 2011. 